\title{
Time in Forensic Sciences
}

\section{Patrice F Dassonville*}

Author of the Invention of Time and Space: Origins, Definitions, Nature, Properties, France

Submission: July 25, 2017; Published: August 09, 2017

*Corresponding author: Patrice F Dassonville, Author of The Invention of Time and Space: Origins, Definitions, Nature, Properties, Rue LatourMaubourg, 06400 Cannes, France, Email: patrice.f.dassonville@gmail.com

\section{Short Communication}

Throughout any criminal investigation, time is among major parameters: dating of events, accuracy and reliability of time data are crucial at each stage of legal proceedings. An interesting questioning is: can we assume that part of the research progress concerning advanced forensic techniques, is in one way or another influenced by the nature of time? Should the properties of time be taken into account? We hope that this compendium $\left(^{*}\right)$ will help answer these questions.

\section{Looking for the Origins of Time}

The Sumerians invented pictographic writing around 3300BC, after geometrizing the ideographic writing and shortly before the occurrence of the first Egyptian hieroglyphs. From 2800 BC, the pictograms led to cuneiform writing. Archeology has uncovered a cuneiform sign (Figure 1) inscribed on a claytablet dated between 2800 and 2500 BC; the sign means lunar month: it's the oldest trace of time in the history of thought. The Sumerians noticed the lunation, which is a physical phenomenon of course, they did not observe the lunar month, which is a concept instead of a phenomenon. Then they started using it as a unit in their everyday life.

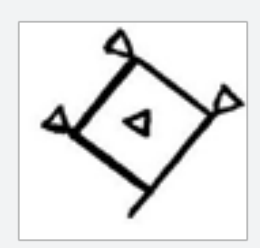

Figure 1: The early stage of time.

\section{Definition of Time Units and Time}

The Figure 2 suggests the best way for simply defining the lunar month without using the words time and duration, which are not defined yet.

The Lunar month is a Concept Corresponding to a Lunation

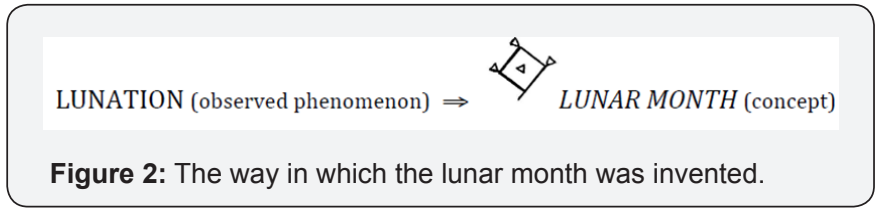

We can then define all the time units in the same way, relative to well known phenomena or in reference to some fundamental constants:

The Year is a Concept Corresponding to a Terrestrial Revolution

The day is a concept corresponding to a terrestrial rotation

The second is a concept corresponding to 9,192,631,770 cesium cycles

It should be recalled that the establishment of time units was quite laborious:

a) The Vulgata Venice (1551), verse I, 1, (5) of Genesis, says: ... fuitvespera fuit que mane dies unus (It was evening, it was morning - one day): it shows us that the biblical day is half of our present day.

b) In Odyssey, Homer writes: When the fourth year came, and when the seasons begin again... (Song II): it means that at the $9^{\text {th }}$ century BC, the year had three months in Greece.

c) In Life of Numa, Plutarch wrote: (the year) only had three months among certain barbarians ... Among Egyptians, the year had one month at first, and later it had four months $(18,6$ \& 7$)$.

d) It certainly explains the extravagancy of the age of the Biblical Patriarchs.

But above all, these contradictions allow us to demonstrate that the units are interpretations of reality; they don't exist in the nature. Year, day and second are concepts, where as terrestrial 
revolution, terrestrial rotation and cesium cycles are physical phenomena.

Time is the n defined in the same way, relative to the physical state of any system:

Time Is a Concept Corresponding To What Separates Two States of a System

\section{Is time a phenomenon?}

It comes out that time was not discovered in the Universe: it's an invention of thought instead of a physical phenomenon. Time has no physical properties, it has only mathematical properties. Therefore time as such is not measurable. For example, we don't measure the duration of an event (Figure 3); instead, we observe what the clock does simultaneously: the result is called Duration of the Event.

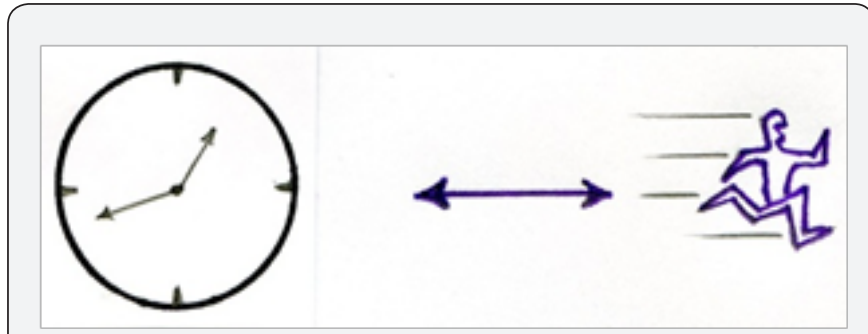

Figure 3: There is no measurement of time.

The runner travels 100 meters $\Leftrightarrow$ the clock indicates 11 seconds

\section{About Aging of Bacteria and Yeast}

We don't measure the lifetime of a bacterium, but we observe what the clock does between the birth of the bacterium and its disappearance: the result is called lifetime of the bacterium. Strictly speaking, there is no measure of lifetime because lifetime is a concept. The aging of a bacterium is not caused by time, but by various physical and chemical factors: indeed, microgravity, or presence of sugar, or suitable temperature, increases the scissi parity rate, i.e. the aging speed of the bacterium. In conclusion: comfort and good food are increasing scissi parity, therefore they are reducing lifetime of bacteria. The Italian gerontologist, Prof. Valet Longo, recently discovered that when yeast is deprived of sugar, its lifetime is doubled. Perhaps we should think about it.

\section{The Etiology of Aging}

Prof. Longo asserts that it's possible to delay the occurrence of diseases by delaying aging. In fact, aging is not the cause of diseases; it's the opposite: diseases, which are phenomena, are among various causes of aging, which is a concept. Time is not a physical phenomenon; therefore it's not the cause of aging. The Medicine distinguishes between chronological age and biological age: a) The chronological age is the official civil age: for everyone, chronological age increases at the same rate.

b) The biological age is dependent on physical and mental state, which is obviously quite difficult to evaluate. Biological age is caused by numerous acquired factors, such as diseases, environmental stressors, lifestyle, hidden or stochastic factors, etc.; and by innate which consists essentially of geneticherit age: similar living beings $A$ and $B$ age differently from each other (Figure 4); this would not be the case if time was the cause of their aging.

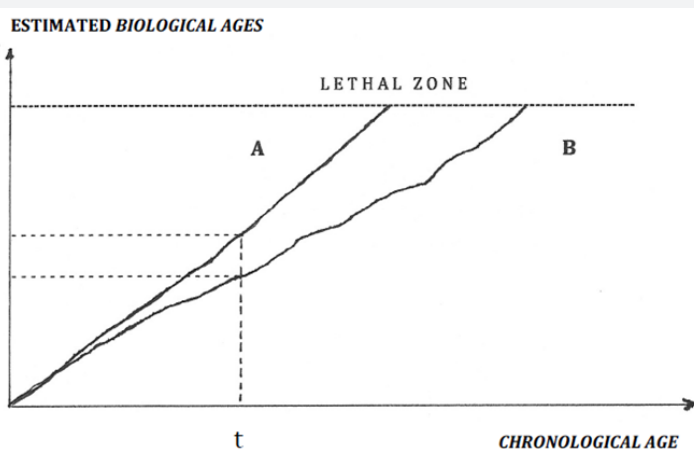

Figure 4: Comparing the estimated biological ages of two individuals $\mathrm{A}$ and $\mathrm{B}$ with the same chronological age, at same age " $t$ ".

\section{Specific Dating Method}

The dating is not a measurement of time; instead, we compare the event with a simultaneous known event; two examples:

I. A pale anthropological dating system: Medication causes gradual wear of the teeth, and the age of an individual at death can be assessed by measuring this wear; there is no measurement of time:

\section{Tooth Wear (Observed) $\Rightarrow$ Age at Death (Concept Of Time)}

II. An entomological dating system: By looking at the stage of development of flylarvaecollescted on a cadaver, forensic medicine of the police can determine the date of death:

Development of larvae (observed) $\Rightarrow$ date of death (concept)

These dating protocols are done without using a clock

\section{Looking for New Dating Protocols}

Time is not a phenomenon. Could it have an influence on practices of the forensic medicine? Will this guide fundamental research towards more efficient processes? 
(C) This work is licensed under Creative (C) Commons Attribution 4.0 License BY DOI: 10.19080/JFSCI.2017.04.555637
Your next submission with Juniper Publishers will reach you the below assets

- Quality Editorial service

- Swift Peer Review

- Reprints availability

- E-prints Service

- Manuscript Podcast for convenient understanding

- Global attainment for your research

- Manuscript accessibility in different formats

( Pdf, E-pub, Full Text, Audio)

- Unceasing customer service

Track the below URL for one-step submission https://juniperpublishers.com/online-submission. 